\title{
JUURNAL.RU
}

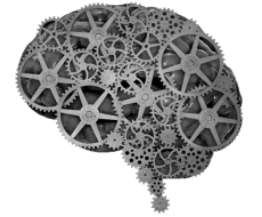

COMPANY GROUP "INTELLEKT"

\author{
Писаненко Д., Кононова С.В., Пономарева А.А., Лебедева М.В. \\ Нижегородская государственная медииинская академия
} Нижний Новгород, Россия

doi: 10.18411/1j2016-5-4-06

\section{Фармакоэкономическая оценка рациональности антибактериальной терапии методом минимизации затрат при проведении дистанционной ударно-волновой литотрипсии}

Мочекаменная болезнь (МКБ) - распространенное урологическое заболевание, которым в современном мире, по данным статистики, страдают около 10-15\% населения развитых стран. МКБ занимает второе место в мире после воспалительных неспецифических заболеваний почек и мочевых путей. При этом в Российской Федерации средние показатели заболеваемости идентичны общемировым. Пациенты с мочекаменной болезнью составляют 30$40 \%$ всего контингента урологических стационаров. У $70 \%$ пациентовМКБ выявляется в наиболее трудоспособном возрасте 30-60 лет. Мочекаменная болезнь зачастую становится причиной снижения трудоспособности и даже инвалидизации, поэтому борьба с данной патологией имеет важное социальное значение.Проблема мочекаменной болезни сохраняет свою актуальность во всем мире в связи с неуклонным ростом заболевания, который ежегодно составляет 0,5-5,3\%.Соотношение мужчин и женщин составляет 52,8 и 47,2\%. [1][7] [8].

Поскольку данное заболевание является мультифокальным, в основе которого лежит взаимодействие генотипа и внешней среды, увеличению частоты МКБ способствуют особенности современного образа жизни, наиболее важные из них: гиподинамия и характер питания - однообразие пищи и обилие в ней белка. Развитие МКБ связано с различными климатическими, 
географическими, жилищными условиями, профессией, наследственными факторами. [5]

В зависимости от причин формирования и состава камни разделяются на несколько типов камнеобразования: кальциевый - до 70\% пациентов, мочекислый - до 12\%,инфицированный - до 15\%,цистиновые камни - до 2-3\%.

Доминирующими в образовании мочевых камней могут быть как причины местного характера: инфекции мочевых путей, анатомические дефекты так и другие патологические изменения в их верхних отделах, приводящие к нарушению нормального оттока мочи, метаболические и сосудистые расстройства. [1] [5].

«Золотым стандартом» лечения мочекаменной болезни является дистанционная ударно-волновая литотрипсия (ДУВЛТ) в связи с малой инвазивностью и высокой эффективностью. ДУВЛТ позволяет удалять около 90\% камней мочевой системы любой локализации. При проведении дистанционной ударно-волновой литотрипсии сфокусированные ударные волны, проникая через ткани и не травмируя их, разрушают камень до мелких фрагментов (песка), который в дальнейшем постепенно выходит с мочой при мочеиспускании. [3]

Особое значение в патогенезе уролитиаза играет мочевая инфекция и хронический пиелонефрит, микроорганизмы способны инициировать и потенцировать камнеобразование. Инфекционный генез имеют 15\% всех камней почек. Доказано, что камни, в состав которых входит струвит, образуются в присутствии фермента уреазы расщепляющего мочевину. Данный фермент образуется благодаря уреазопродуцирующим бактериям, к которым относятся почти все виды протея, а также стафилококк, клебсиелла, некоторые виды грибов и микоплазмы. Как вторичное инфицирование, при мочекаменной болезни, рассматривается микробная культура, обусловленная микроорганизмами, не продуцирующими уреазу (E. coli, и др.). Часто камни сами являются источниками инфекции, в 41,3\% случаев отмечается наличие 
микроорганизмоов в камне при стерильной пузырной моче, вследствие чего она не может быть показателем отсутствия инфекции. Необходимо так же отметить: риск рецидива мочекаменной болезни при асептических камнях составляет 35\%, а при инфицированных 10-12\%это обуславливает необходимость применения антибактериальных препаратов в лечении мочекаменной болезни.[2] [4] [6]

Целью исследования являлось проведение фармакоэкономического анализа схем антибактериальной терапиипри проведении дистанционной ударно-волновой литотрипсии.

Материалы и методы. Ретроспективно проанализированы 85 историй болезни пациентов, находившихся на лечении в урологическом стационаре г. Нижнего Новгорода в 2013-2014 годах. Среди них 54\% мужчин и 46\% женщин, средний возраст пациентов составил 46 лет.

Результаты и их обсуждение. Эффективность антибактериальной терапии была признана одинаковой для всех препаратов, длительность госпитализации определялась течением мочекаменной болезни.Для проведения сравнительной оценки препаратов использовался анализ минимизации затрат, расчет проводился по формуле:

$C M A=D C 1-D C 2$, где

СМА - показатель разницы затрат,

DC1 - прямые затраты при применении 1-го метода,

DC2 - прямые затраты при применении 2-го метода.

Под прямыми затратами понимались расходы на антибактериальные препараты, прочие прямые и косвенные затраты были признаны одинаковыми во всех группах.При анализе использовалась стоимость суточных доз препаратов, исходя из средних закупочных цен в 2013-2014 гг.В зависимости от назначенных антибактериальных препаратов пациенты были разделены на группы (Таблица 1). 
Лекарственные препарать, применяемье для антибактериальной терапии при $M K Б$

\begin{tabular}{|c|c|c|}
\hline Антибактериальный препарат* & Количество пациентов & Стоимость 1 дня терапии \\
\hline Фосфомицин (Монурал) (п) & 20 & 559,1 \\
\hline $\begin{array}{c}\text { Амоксициллин/клавуланат } \\
\text { (Аугментин) (и) }\end{array}$ & 14 & 49,4 \\
\hline Офлоксацин (и) & 20 & 48,6 \\
\hline $\begin{array}{c}\text { Амоксициллин/клавуланат } \\
\text { (Аугментин) (п) }\end{array}$ & 11 & 31,4 \\
\hline \multicolumn{2}{|c|}{ Фуразидин (Фурамаг) (п) } \\
\hline \multicolumn{2}{|c|}{ * - пероральная, и - инъекционная формы лекарственных препаратов } \\
\hline
\end{tabular}

Наименее затратной оказалась терапия с использованием Аугментина (таблетки)- 48,6 руб.и Фурамага- 31,4 руб.Наиболее дорогостоящим лекарственным препаратом (ЛП)оказался Монурал - 559,1 руб.

ЛП были проранжированы по стоимости курса антибактериальной терапии.Стоимость курса рассчитываласьисходя из стоимости 1 дня терапии и среднего времени госпитализации (7,5 дней), за исключением Монурала, который применялся однократно. Наиболее затратным оказался курс терапии инъекционным формой Аугментина (2454 руб.), наименее затратен курс Фурамага (129 руб.) (Таблица 2).

Таблица 2

Стоимость курсов антибактериальной терапии при МКБ

\begin{tabular}{|c|c|c|}
\hline Антибактериальный препарат* & Стоимость курса & СМА \\
\hline Аугментин) (и) & 2454 & 1894,9 \\
\hline Монурал (п) & 559,1 & 188,6 \\
\hline Офлоксацин (и) & 370,5 & 6 \\
\hline Аугментин (п) & 364,5 & 129 \\
\hline Фурамаг (п) & 235,5 & \\
\hline \multicolumn{2}{|c|}{ *п - пероральная, и - инъекционная формы лекарственных препаратов } \\
\hline
\end{tabular}

Выводы. Исходя из результатов фармакоэкономического анализа, наиболее рациональным препаратом для проведения антибактериальной терапиипри мочекаменной болезни является фуразидин. Наименее экономически выгодным - Амоксициллин/клавуланат (в инъекционной форме). 
Использование инъекционных препаратов менее оправдано по сравнению с пероральными с экономической точки зрения.

\section{Литература:}

1. Аполихин О.И., Какорина Е.П., Сивков А.В., Бешлиев Д.А., Солнцева T.В., Комарова В.А. Состояние урологической заболеваемости в Российской Федерации по данным официальной статистики. // Урология. 2008. №3. C. 3-9.

2. Вощула В.И., Лыш Е.Я., Станкевич С.И. Инфекция в этиопатогенезе мочекаменной болезни // Медицинские новости.-2007.-№11.- С. - 113-118.

3. Канн Я.Д. Оценка эффективности литотрипсии при нефроуретеролитиазе/ Я.Д. Канн, И.В. Гальчиков, А.Ю. Росляков // Урология. 2003. №5. С.63-69.

4. Ларцова Е.В., Спивак Л.Г., Морозова О.А. Бактериальная обсемененность мочи у пациентов с крупными и коралловидными камнями почек. // Вестник урологии. - 2015, №2. С. 34-40.

5. Лопаткин Н.А. Урология основная специальность / Н.А. Лопаткин, О.И. Аполихин // Урология. - 2004. - №1.- С.9-12.

6. Палагин И.С., Сухорукова М.В., Дехнич А.В., Эйдельштейн М.В., Шевелев А.Н., Гринев А.В., Перепанова Т.С., Козлов Р.С. Современное состояние антибиотикорезистентности возбудителей внебольничных инфекций мочевых путей в россии: результаты исследования «ДАРМИС» (2010-2011) Клиническая микробиология и антимикробная химиотерапия. 2012. T. 14. № 4. C. 280-302.

7. Coe F.L, Favus M.J., Рак C.Y. etal. Medical and Surgical Management // Europ. Urol. 2007. - V.31. - N 1. - P. 17-23.

8. Daudon M. Les lithiasesurinairesmedicamenteuses. Drug-induced urinary calculi // Prog. Urol. 2011. N 8. - P. 1023-1033. 